\title{
Geochemical signatures of Lower Gondwana sandstones of eastern Arunachal Himalayas, India: Implications for tectonic setting, provenance and degree of weathering
}

\author{
Bashab N. Mahanta ${ }^{1}$, B. R. Syngai ${ }^{2}$, R. K. Sarmah ${ }^{3}$, T. K. Goswami ${ }^{3}$, and Amit Kumar ${ }^{4}$ \\ Received 24 October 2019; accepted 9 December 2019; published 13 May 2020.
}

The compositional variability of the sandstones leads to insight about the controlling sedimentary processes and plate tectonic environments. The geochemical composition of the Lower Gondwana sandstones exposed along the Main Boundary Thrust in parts of East Siang and West Siang districts of Arunachal Pradesh, India was determined to deduce their provenance and tectonic setting governing their deposition. The overall analyses of the samples from the study area reveals the chemically coherent nature of the sediments and derivation from rocks of acidic and intermediate compositions. Trace element concentrations of the rocks of the study area are in concurrence with average Upper Continental Crust (UCC) whereas the Rare Earth Element (REE) values indicate felsic source rocks. Discrimination of tectonic setting using oxide data indicates passive margin setting for the sediments. The Chemical Alteration Index (CIA) was calculated and indicates medium to high chemical weathering during sedimentation of the basin. KEYWORDS: Gondwana; sandstone; Himalayas; geochemistry; tectonic setting; weathering.

Citation: Mahanta, Bashab N., B. R. Syngai, R. K. Sarmah, T. K. Goswami, and Amit Kumar (2020), Geochemical signatures of Lower Gondwana sandstones of eastern Arunachal Himalayas, India: Implications for tectonic setting, provenance and degree of weathering, Russ. J. Earth. Sci., 20, ES2003, doi:10.2205/2020ES000698.

\subsection{Introduction}

The geochemistry of sedimentary, igneous and metamorphic rocks is very important apart from petrographic and isotopic studies in deciphering the provenance, weathering, diagenesis and transportation. Even though diagenesis may alter original chemistry, changes are themselves related to

\footnotetext{
${ }^{1}$ Geological Survey of India, Shillong, Meghalaya, India

${ }^{2}$ Geological Survey of India, Kolkata, West Bengal, India

${ }^{3}$ Dept. of Applied Geology, Dibrugarh University, Assam, India

${ }^{4}$ Geological Survey of India, Chandigarh, India
}

Copyright 2020 by the Geophysical Center RAS. http://rjes.wdcb.ru/doi/2020ES000698-res.html plate tectonic environment [Siever, 1979], and bulk composition reflect tectonic setting and so enable development of chemically-based discriminant to supplement the petrographic approach [Roser and Korsch, 1986]. The compositional variability of sedimentary rocks especially sandstone commonly leads to insight about provenance and attendant sedimentary processes. Key trace elements or isotopes systems may be of considerable importance in understanding tectonic history [McLennan et al., 1993 . An attempt was made to study the elemental geochemistry of the Lower Gondwana Group of rocks exposed in the Eastern Arunachal Himalayas to decipher the possible provenance, tectonic setting, weathering history and the results are presented in this paper. The major oxide analysis was used for geochemical classification of the sandstones and inferences were made on the prove- 


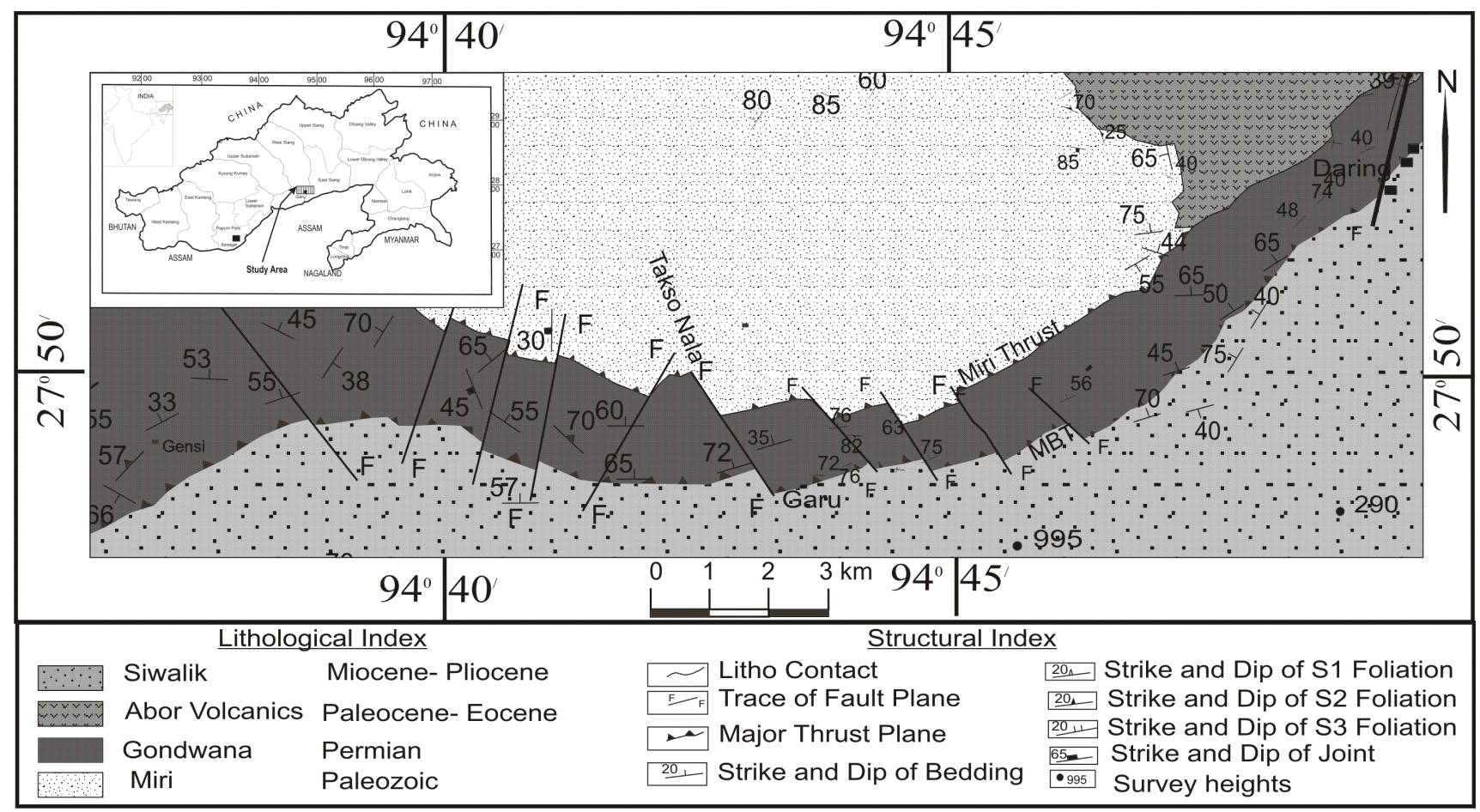

Figure 1. Geological Map of the study area (after Mahanta et al. 2019).

nance and tectonic setting using various discriminant functions. Trace and REE compositions were used to decipher the provenance of the sandstones and also to understand the degree of source area weathering.

\subsection{Location and Geological Setting}

Geographically, the area falls in the Lesser Himalayas and is located at the southwestern part of the Siang Dome in the districts of East Siang and West Siang of the state of Arunachal Pradesh, India (Figure 1). The Gondwana rocks in the area occur as a linear belt trending WSW-ENE. They belong to the Bichom Formation of the Lower Gondwana Group and overlain by the Miri Group of rocks along Miri Thrust. Towards South, the Gondwana are thrusted over the Siwalik Supergroup of rocks. The Bichom Formation can be divided into Rilu and Bomte members. The Rilu member is represented by diamictite, orthoquartzite, khaki shale, coal, carb shale, siltstone, sandstone, concretions with marine fossils and belongs to the marine facies. The Oscillatory streaky (deltaic) facies is represented by the Bomte mem- ber comprising carb shale, grey shale, coal, shaly coal, sandstone occasionally with marine fossils [Mahanta et al., 2017, 2019. A generalised stratigraphic sequence of the area after GSI, 2010 is given in Table 1 .

\subsection{Petrography}

Three varieties of sandstones viz. quartz rich sandstone, ferruginous sandstone and calcareous sandstone have been recognized by petrography. The detrital framework grains comprise of high proportion of quartz, very low proportion of feldspar and mica with considerable amount of lithic fragments. The most abundant mineral of the sandstones is quartz followed by rock fragments and feldspar [Mahanta et al., 2019]. Both sedimentary and metamorphic rock fragments are observed in the sandstones with minor amount of chert and volcanic lithics. Both biotite and muscovite of detrital and diagenetic origin are present in the sandstones. The sandstone is moderate to poorly sorted, matrix supported and shows textural sub maturity. The heavy mineral assemblage includes chlorite, biotite, zircon, ilmenite, epidote, 
Table 1. Lithostratigraphic Succession of the Study Area (After [GSI, 2010])

\begin{tabular}{|c|c|c|c|}
\hline Age & Supergroup & Group & Lithology \\
\hline $\begin{array}{l}\text { Miocene-- } \\
\text { Pliocene }\end{array}$ & Siwalik & & $\begin{array}{l}\text { Micaceous, hard Sandstone and shale intercalated } \\
\text { with nodular clay beds, Felspathic sandstone, } \\
\text { claystone, siltstone, shale with calcareous nodules } \\
\text { plant fossils and occasional coal, petrified wood. }\end{array}$ \\
\hline $\begin{array}{l}\text { Paleocene- } \\
\text { Eocene }\end{array}$ & & Abor & $\begin{array}{l}\text { Basic volcanics with pyroclast and volcanogenic } \\
\text { sediments with occasional limestone. }\end{array}$ \\
\hline Permian & Gondwana & $\begin{array}{l}\text { Lower Gondwana } \\
\text { (Bichom Fm) }\end{array}$ & $\begin{array}{l}\text { Diamictite, orthoquartzite, grey shale, coal, } \\
\text { carbonaceous shale, siltstone, sandstone } \\
\text { Carbonaceous shale, grey shale. }\end{array}$ \\
\hline Palaeozoic & & Miri & $\begin{array}{l}\text { Skolithos bearing pink quartzite, Orthoquartzite, } \\
\text { bands of phyllite and occassional conglomerate. }\end{array}$ \\
\hline
\end{tabular}

garnet, amphibole, chloritoid, brown tourmaline, magnetite, staurolite, rutile, and opaques [Mahanta et al., 2017, 2019.

\subsection{Sandstone Geochemistry}

Thirty three sandstone samples were collected from the study area and were analyzed at Chemical Division, Shillong and Central Petrological Laboratory, Kolkata of Geological Survey of India for major oxides by XRF and trace and rare earth elements by Inductively Coupled Plasma Mass Spectrometry (ICP-MS). The analytical results obtained from sandstones of Lower Gondwana Group of Eastern Arunachal Himalaya are arranged in four tables [Mahanta et al., 2020] published in Earth Science Data Base, created and managed by GCRAS.

2.2.1. Major Oxides. The Gondwana sandstones are mainly composed of $\mathrm{SiO}_{2}(41.12-76.76 \%$, avg.57.99\%) followed by $\mathrm{Al}_{2} \mathrm{O}_{3}$ (5.03-23.86\%, avg. $16.19 \%), \mathrm{Fe}_{2} \mathrm{O}_{3} \quad\left(2.11-32.24 \%\right.$, avg. $6.68 \mathrm{~K}_{2} \mathrm{O}$ (0.65-8.16\%, avg. 2.72\%), $\mathrm{MgO}(1.05-2.49 \%$, avg. $1.87 \%), \mathrm{CaO}$ (0.09-22\%, avg. 2.70\%), $\mathrm{Na}_{2} \mathrm{O}$ (0.05-5.57\%, avg. $0.93 \%)$, $\mathrm{MnO}(0.01-1.84 \%$, avg. $0.16 \%), \mathrm{TiO}_{2}(0.31-1.16 \%$, avg. $0.70 \%)$ and $\mathrm{P}_{2} \mathrm{O}_{5}$ (0.03-2.6\%, avg. 0.27\%) [Mahanta et al., 2020, Table 1].

In the samples, $\mathrm{SiO}_{2}$ shows negative correlation with all major elements. Positive correlation of $\mathrm{Al}_{2} \mathrm{O}_{3}$ with $\mathrm{K}_{2} \mathrm{O}(r=0.64)$ and $\mathrm{TiO}_{2}(r=0.58)$, $\mathrm{TiO}_{2}$ with $\mathrm{K}_{2} \mathrm{O}(r=0.10), \mathrm{Na}_{2} \mathrm{O}(r=0.37), \mathrm{Fe}_{2} \mathrm{O}_{3}$ with $\mathrm{MnO}(r=0.92), \mathrm{P}_{2} \mathrm{O}_{5}(r=0.84), \mathrm{MgO}$ with $\mathrm{K}_{2} \mathrm{O}(r=0.40)$ was observed [Mahanta et al.,2020, Table 3].

\subsubsection{Trace and Rare Earth Elements.} Trace element concentrations of the samples are in agreement with the average upper continental crust (UCC) with the exception of Th, Sr, K, Nb, Sr, P and $\mathrm{Zr}$ [Mahanta et al.,2020, Table 1]. In the study area $\mathrm{Cr}$ (average value $77.87 \mathrm{ppm}$ ) and V (average value $157.72 \mathrm{ppm}$ ) is enriched while $\mathrm{Ni}$ (average value $40.75 \mathrm{ppm}$ ) and Co (average value $17.78 \mathrm{ppm}$ ) are depleted with respect to the average composition of the UCC. The Sr content is in the range of 25-447 ppm. Among the transitional elements (Co, $\mathrm{Cu}, \mathrm{Ni}, \mathrm{Zn}, \mathrm{Cr}$ ), Co exhibit positive correlations with $\mathrm{Al}_{2} \mathrm{O}_{3}(r=0.17), \mathrm{TiO}_{2}(r=0.42), \mathrm{Fe}_{2} \mathrm{O}_{3}$ $(r=0.28), \mathrm{MnO}(r=0.15)$, and negative correlation with $\mathrm{K}_{2} \mathrm{O}(r=-0.21), \mathrm{CaO}(r=-0.05) . \mathrm{Cu}$ shows positive correlations with $\mathrm{Al}_{2} \mathrm{O}_{3}(r=0.148)$, $\mathrm{TiO}_{2}(r=0.23), \mathrm{Fe}_{2} \mathrm{O}_{3}(r=0.023)$, negative correlation with $\mathrm{MnO}(r=-0.05), \mathrm{K}_{2} \mathrm{O}(r=-0.05)$ and $\mathrm{CaO}(r=-0.08)$. Ni shows positive correlation with $\mathrm{TiO}_{2}(r=0.52), \mathrm{Fe}_{2} \mathrm{O}_{3}(r=0.25), \mathrm{MnO}$ $(r=0.13), \mathrm{Na}_{2} \mathrm{O}(r=0.33)$ and negative correlation with $\mathrm{SiO}_{2}(r=-0.25), \mathrm{Al}_{2} \mathrm{O}_{3}(r=-0.01)$ and $\mathrm{K}_{2} \mathrm{O}(r=-0.36)$. Zn shows negative correlation with $\mathrm{Fe}_{2} \mathrm{O}_{3}(r=-0.14), \mathrm{MnO}(r=-0.24)$ and positive correlation with other major oxides. $\mathrm{Cr}$ shows negative correlation with $\mathrm{Fe}_{2} \mathrm{O}_{3}, \mathrm{MnO}, \mathrm{MgO}$ and $\mathrm{CaO}$, strong positive correlation with $\mathrm{TiO}_{2}$, $\mathrm{Al}_{2} \mathrm{O}_{3}$, and weak positive correlation with $\mathrm{SiO}_{2} \cdot \mathrm{Cr}$ shows positive correlations with $\mathrm{Ni}(r=0.124)$ and 
$\mathrm{Zn}(r=0.518)$. Ni shows positive correlations with $\mathrm{Co}(r=0.399)$ and $\mathrm{Cu}(r=0.41)$. Co abundances show significant positive correlation with $\mathrm{Ni}, \mathrm{V}$ and positive correlation of $\mathrm{Sc}$ with $\mathrm{Ni}$ and $\mathrm{Al}_{2} \mathrm{O}_{3}$ was observed [Mahanta et al., 2020, Table 3].

The REE and Sc values in the sediments provide reliable information on source rock due to their relatively low mobility during sedimentation [Bhatia and Crook, 1986, Rahman and Suzuki, 2007. The ratios of $\mathrm{La} / \mathrm{Sc}, \mathrm{Th} / \mathrm{Sc}, \mathrm{La} / \mathrm{Co}, \mathrm{Th} / \mathrm{Co}$, and $\mathrm{Cr} / \mathrm{Th}$ also indicate about the provenance of sedimentary rocks and its mafic or acidic character [Cullers et al., 1988, Cullers, 1994, 2000, Cullers and Podkovyrov, 2000; Rahman and Suzuki, 2007. The values of $\mathrm{La} / \mathrm{Sc}, \mathrm{Th} / \mathrm{Sc}, \mathrm{La} / \mathrm{Co}, \mathrm{Th} / \mathrm{Co}$, and $\mathrm{Cr} / \mathrm{Th}$ values of the Lower Gondwana Group sandstones are in the ranges of $0.019-6.74,0.39-3.37,0.07-15.4$, 0.50-14.40 and 0.06-8.83 respectively [Mahanta et al., 2020, Table 2, 4].

\subsection{Discussions}

It is indispensable that geochemical characteristics of various modern and ancient sandstone suites be understood in order to categorize signatures of source rocks and tectonic settings in their compositions, and to deduce the redistribution of elements during and after deposition [Bhatia, 1983]. Concentration of the major oxides, trace elements and REEs and some of the ratios were used to decipher important clues regarding the provenance of the Gondwana sandstones. The different discrimination diagrams proposed by several workers also were used to decode the provenance and tectonic setting as well as source area weathering.

3.1.1 Composition and Classification of the Sandstones. From the major oxide composition of the sandstones, it was observed that $\mathrm{SiO}_{2}$ is showing negative correlation with all the major oxides which indicate that bulk of the $\mathrm{SiO}_{2}$ is present as free quartz. The positive correlation of $\mathrm{Al}_{2} \mathrm{O}_{3}$ with $\mathrm{K}_{2} \mathrm{O}$ suggests that $\mathrm{K}$-bearing minerals have + ve influence on $\mathrm{Al}$ distribution and suggests that $\mathrm{Al}$ and $\mathrm{K}$ is primarily contributed by clay minerals (e.g., illite) [McLennan et al., 1983. Higher values of $\mathrm{K}_{2} \mathrm{O} / \mathrm{Na}_{2} \mathrm{O}$ ratio (average $=8.16$ ) $[\mathrm{Ma}$ hanta et al., 2020. Table 4] indicate the presence of K-bearing minerals such as K-feldspar, muscovite and biotite in the rocks [McLennan et al.,
1983. Nath et al., 2000 Osae et al., 2006. High content of $\mathrm{Fe}_{2} \mathrm{O}_{3}$ (average $6.68 \%$ ) indicates that a part of the $\mathrm{Fe}_{2} \mathrm{O}_{3}$ was possibly precipitated as limonite/goethite during sedimentation and/or diagenesis. $\mathrm{CaO}$ exhibits negative correlation with $\mathrm{SiO}_{2}(r=-0.36)$ suggesting that the carbonates are primary rather than secondary [Feng and Kerrich, 1990.

From the trace element composition, following inferences can be brought out. The abundances of Ba (average $459.60 \mathrm{ppm}$ ), suggest that the concentrations of these trace elements are controlled by clay minerals and mica [McLennan et al., 1993. Ba content usually varies between 11 and $300 \mathrm{ppm}$ [Bellanca et al., 1999]. Ba is sometimes related to clay minerals or iron oxides. Its richness in sediments can be considered as an indicator of a high influx of biogenic material to the sediments and also of high surface-water productivity [Dymond et al., 1992, Schmitz, 1987. Positive correlation of Co with $\mathrm{Ni}(r=0.29)$, and positive correlation of Sc with $\mathrm{Ni}(r=0.21)$ and $\mathrm{Al}_{2} \mathrm{O}_{3}(r=0.19)$ infers that $\mathrm{Co}$ and $\mathrm{Sc}$ are partly controlled by chlorite and other accessory nonaluminous silicate minerals [Rahman and Suzuki, 2007].

According to the diagram of Herron [1986] based on the concentration of $\mathrm{SiO}_{2}, \mathrm{Al}_{2} \mathrm{O}_{3}$ and $\mathrm{Fe}_{2} \mathrm{O}_{3}$, the sandstones are classified mainly as litharenites and wackes $($ Figure $2 \mathrm{a})$. In the $\mathrm{K}_{2} \mathrm{O}-\mathrm{Na}_{2} \mathrm{O}$ diagram of Crook 1974, samples are plotted in the quartz rich field (Figure 2b).

\subsubsection{Provenance and Tectonic Setting.} High Values of $\mathrm{Al}_{2} \mathrm{O}_{3} / \mathrm{TiO}_{2}$ ratio (avg = 23.87) [Mahanta et al., 2020, Table 4] of the Gondwana sandstones indicate derivation of the detrital material from a continental source [Fyffe and Pickerill, 1993 . The enriched $\mathrm{Cr}$ and depleted $\mathrm{Ni}$ in the sandstones are suggestive of some ultramafic source for the rocks [Rahman and Suzuki, 2007]. It was observed that Th, P, Sm and Y are enriched and $\mathrm{K}, \mathrm{Nb}, \mathrm{Zr}$ and $\mathrm{Sr}$ are depleted in the sandstones. Negative anomalies were observed in Rb, $\mathrm{Nb}$ and $\mathrm{Tb}$ (Figure 3). These anomalies indicate both cratonic and quartzose recycled sediments deposited in a passive margin tectonic setting [Peterson, 2009.

Harker diagrams were used to compare the abundances of the major oxides against $\mathrm{SiO}_{2}$. The diagram shows negative correlation of $\mathrm{SiO}_{2}$ with $\mathrm{TiO}_{2}$, $\mathrm{Al}_{2} \mathrm{O}_{3}, \mathrm{Fe}_{2} \mathrm{O}_{3}, \mathrm{MnO}, \mathrm{MgO}, \mathrm{CaO}, \mathrm{Na}_{2} \mathrm{O}$ and $\mathrm{K}_{2} \mathrm{O}$ 


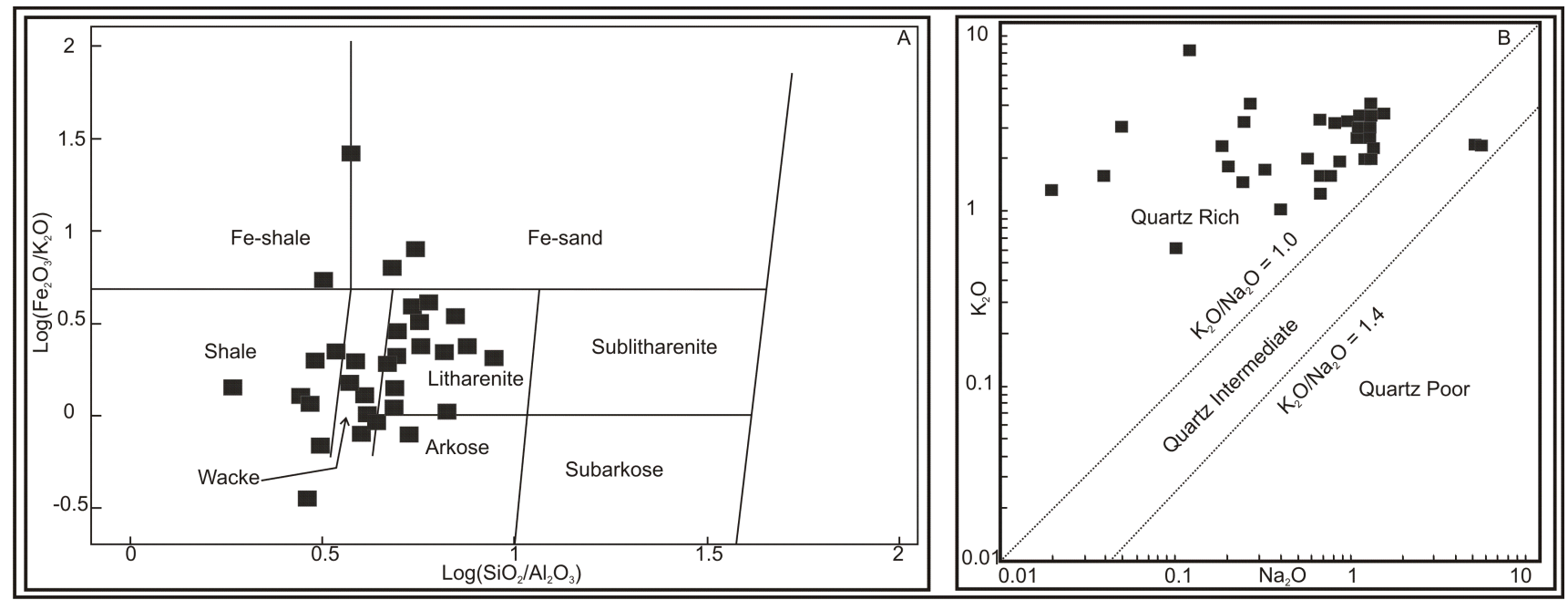

Figure 2. A) Chemical classification of the Lower Gondwana Group sandstones (after Herron [1986]), B) analysis of the rocks of the study area according to the richness of quartz (after Crook 1974).

and the decrease of these elements as $\mathrm{SiO}_{2}$ increases indicates a passive margin average [Peterson, 2009 for the sandstones (Figure 4).

Sandstone samples from the study area have uniform $\mathrm{K} / \mathrm{Rb}$ ratios that lie around a typical differentiated magmatic suite or main trend with a ratio of 230 (Figure 5) [Shaw, 1968. This indicates chemical coherency of the sediments and point towards acidic and intermideiate rocks as source rocks $[$ Rahman and Suzuki, 2007.

Various classifications have been proposed to dis- criminate sediments from various origins and tectonic settings using major elements [Maynard et al., 1982, Bhatia, 1983, Bhatia and Crook, 1986, Roser and Korsch, 1986, 1988. Discrimination diagram proposed by Bhatia 1983 include the fields of oceanic island arc, continental island arc, active continental margin and passive margin in the plots of $\mathrm{Al}_{2} \mathrm{O}_{3} / \mathrm{SiO}_{2}$ versus $\mathrm{Fe}_{2} \mathrm{O}_{3}+\mathrm{MgO}: \mathrm{K}_{2} \mathrm{O} / \mathrm{Na}_{2} \mathrm{O}$ versus $\mathrm{Fe}_{2} \mathrm{O}_{3}+\mathrm{MgO}: \mathrm{Al}_{2} \mathrm{O}_{3} /\left(\mathrm{CaO}+\mathrm{Na}_{2} \mathrm{O}\right)$ versus $\mathrm{Fe}_{2} \mathrm{O}_{3}+\mathrm{MgO}$ and $\mathrm{TiO}_{2}$ versus $\mathrm{Fe}_{2} \mathrm{O}_{3}+\mathrm{MgO}$ (Figure $6 \mathrm{a}$, Figure $6 \mathrm{~b}$, Figure 6c, Figure 6 d). In these

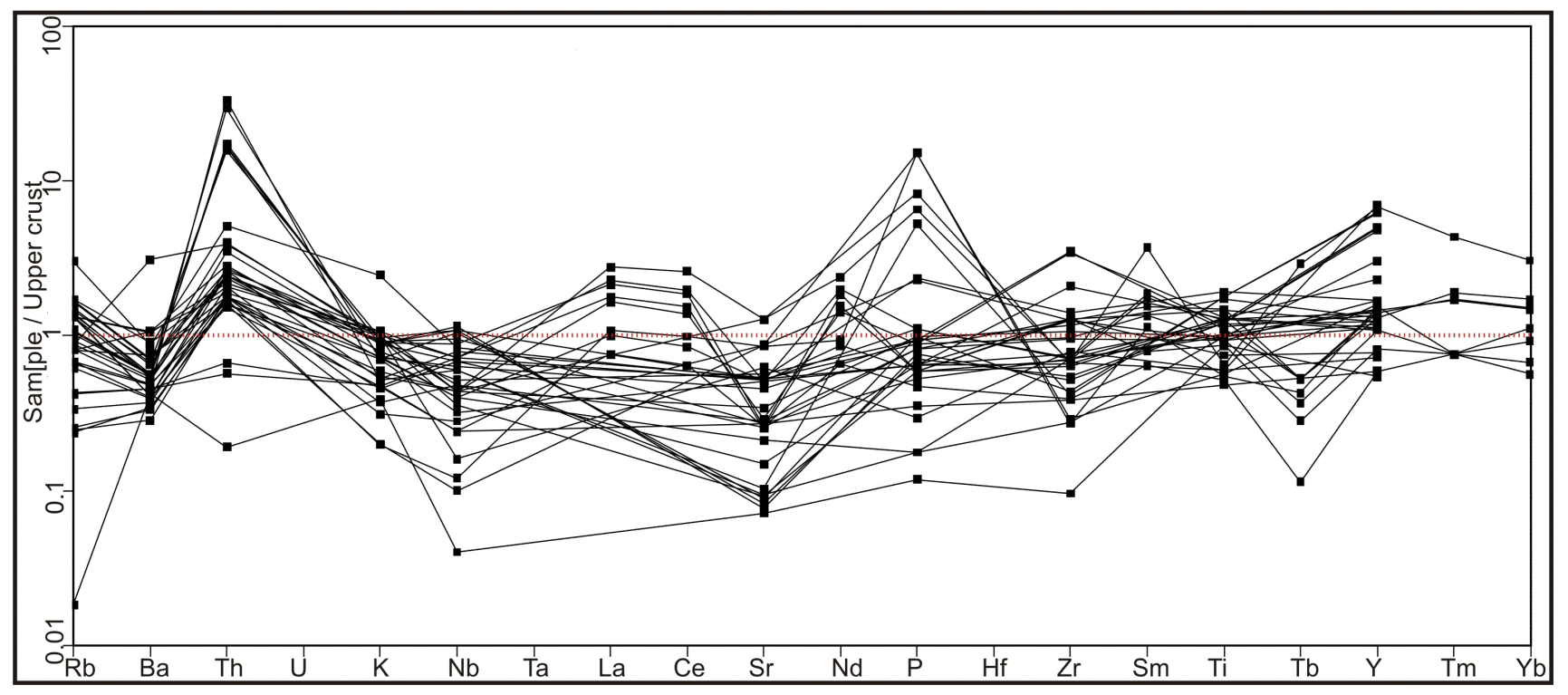

Figure 3. Multi-element normalized diagram for the Gondwana sandstones, normalized against Upper Continental Crust, (after Taylor and McLennan 1985). 


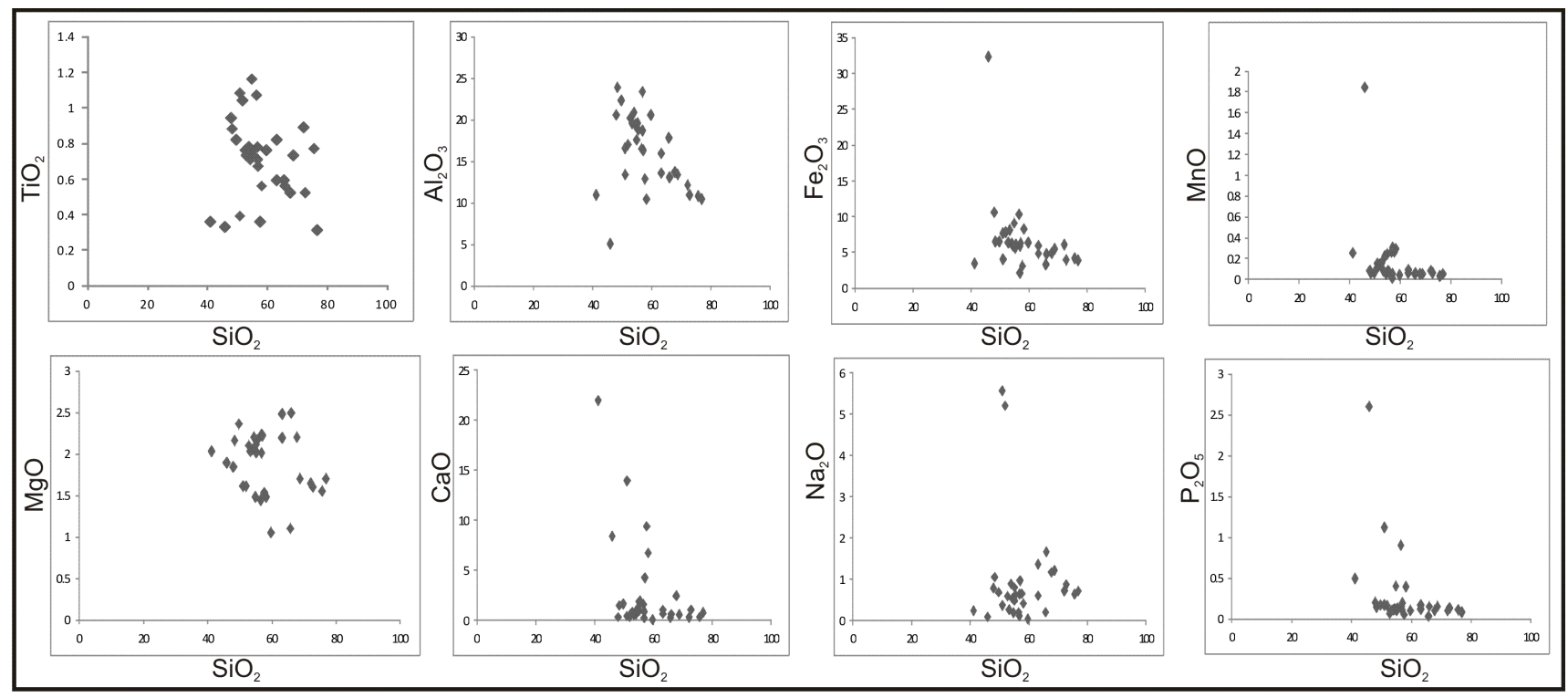

Figure 4. Harker diagram for major oxides in the study area.

plots, samples were plotted in no well defined field but in overlapping fields. Most of the samples fall in fields of continental island arc, active continental margin, and a few in passive margin fields with much scatter. However, Peterson 2009 showed that active continental margins as defined by $B h a-$ tia 1983 are not the same as continental arc and cannot be distinguished from cratonic interior sed-

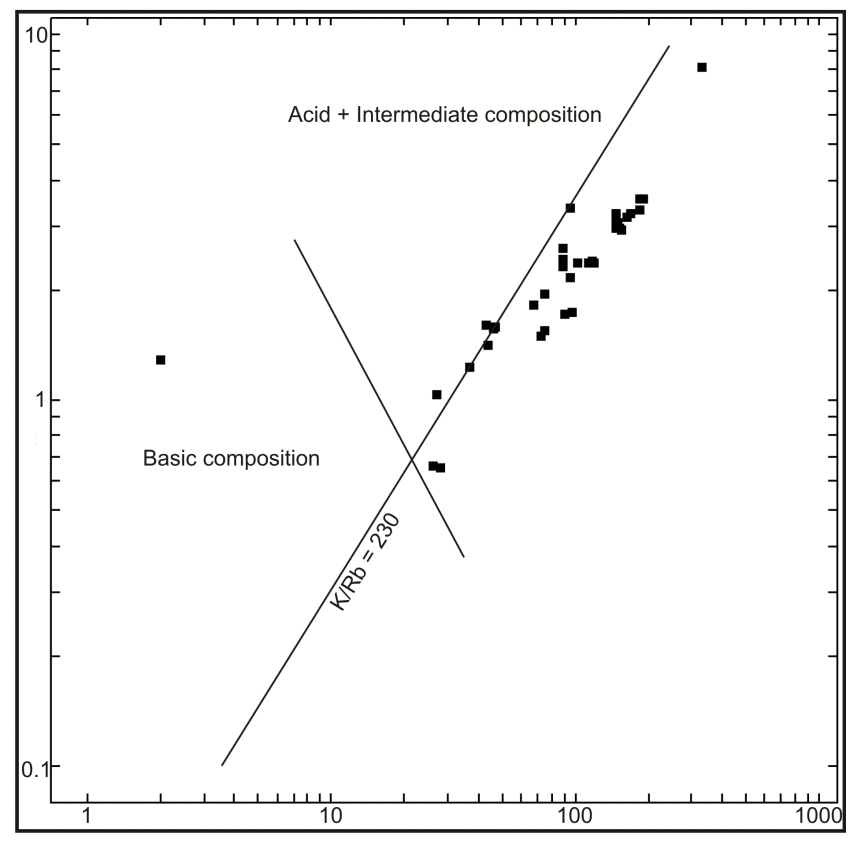

Figure 5. Distribution of $\mathrm{K}$ and $\mathrm{Rb}$ of the rocks of the study area (after Shaw 1968). iments deposited on a passive margin. Though extensively used, the plots of Bhatia 1983 could not provide much information regarding the tectonic setting in this particular study. According to [Armstrong-Altrin and Verma, 2005, the failure of this diagram to clearly identify the tectonic settings is due to use of average values, improper representaion of the tectonic settings and they indicated that the diagram proposed by Roser and Korsch 1986 produce better results.

In the diagram of Roser and Korsch 1986 using $\log \left(\mathrm{K}_{2} \mathrm{O} / \mathrm{Na}_{2} \mathrm{O}\right)$ versus $\mathrm{SiO}_{2}$, the majority of the sandstones samples plot in the passive margin field (Figure 7a.) Another discriminants function diagram proposed by Roser and Korsch 1988 to distinguish the nature of provenance was used and the samples dominantly represent the felsic igneous province and some samples fall in the intermediate igneous province (Figure $7 \mathrm{~b})$.

The Lanthanum-Thorium-Scandium plot of Bhatia and Crook 1986 can distinguish arc-derived sediments and passive margin sediments from each other but fails to separate active continental margin and passive margin sediments. On this diagram (Figure 7c) most of the samples are plotted within active and passive continental margin environment which indicate derivation of these sediments from a predominantly granite and granodioritic source.

$\mathrm{Th} / \mathrm{Sc}$ ratio in combination with $\mathrm{Zr} / \mathrm{Sc}$ ratio has been considered a strong indicator of the provenance. Th/Sc ratio is an index of fractionation of 


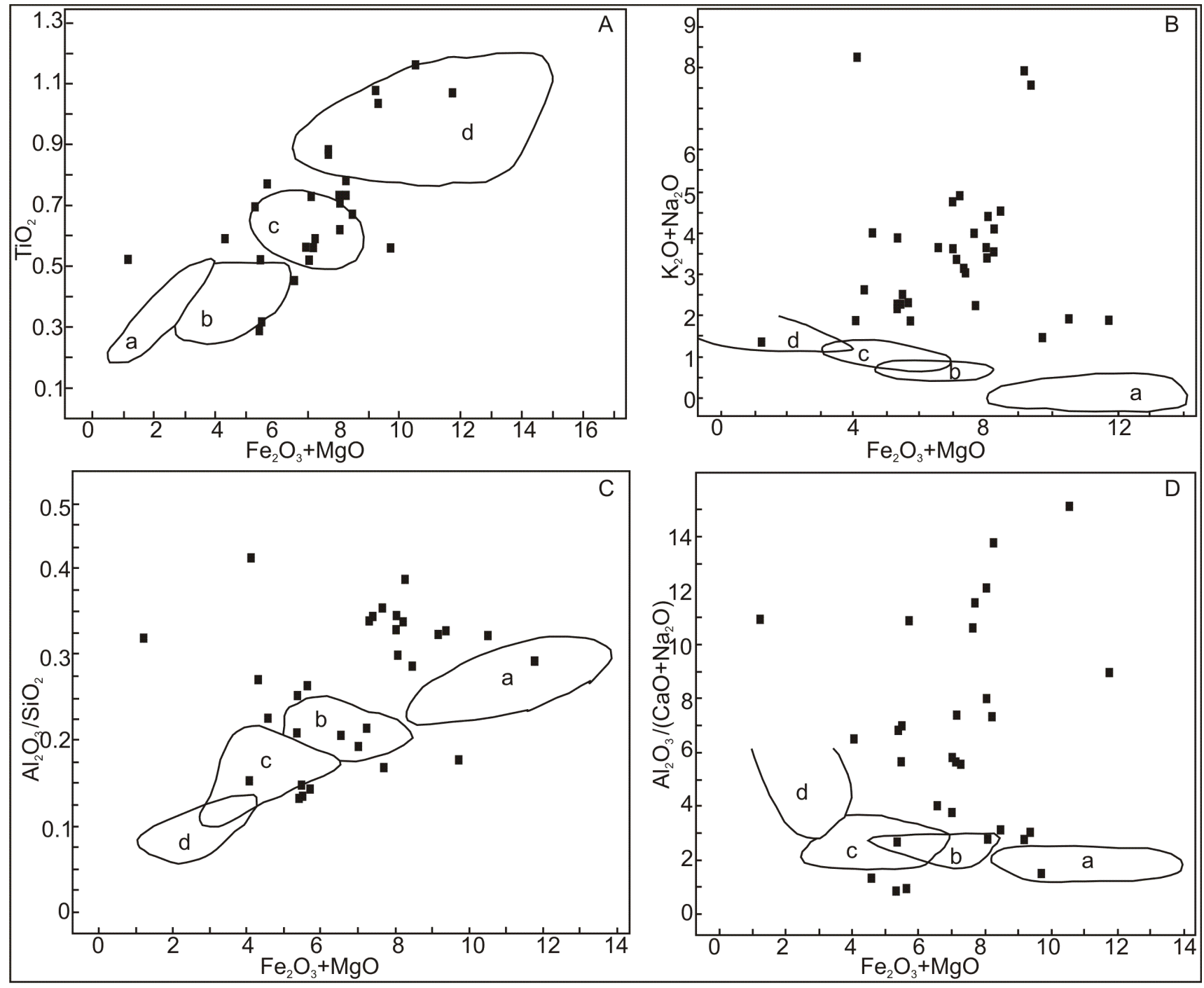

Figure 6. Tectonic-setting discrimination diagrams for rocks of the study area. Boundaries are after Bhatia 1983, $\mathrm{a}=$ Oceanic island arc margin, $\mathrm{b}=$ Continental island arc, $\mathrm{c}=$ Active continental margin, $\mathrm{d}=$ Passive margin .

magmatic source rocks, whereas, $\mathrm{Zr} / \mathrm{Sc}$ ratio is a helpful index of zircon enrichment, because $\mathrm{Zr}$ is highly enriched in zircon [McLennan et al., 1993]. Therefore, $\mathrm{Zr} / \mathrm{Sc}$ ratios show the grade of reworking of clastic sediments. However, increased $\mathrm{Zr} / \mathrm{Sc}$ with constant $\mathrm{Th} / \mathrm{Sc}$ indicates first cycle recycling or sediments with plutonic provenance [Roser and Korsch, 1999, Rahman et al., 2014. Vdacny et al., 2013. Thus $\mathrm{Th} / \mathrm{Sc}$ and $\mathrm{Zr} / \mathrm{Sc}$ variation diagram may be used to constrain sorting and recycling processes [McLennan et al., 1993]. Th/Sc ratio $<0.8$ is an indicator of source other than the typical continental crust, probably of mafic source or input from mature or recycled source if coupled with higher ratio of $\mathrm{Zr} / \mathrm{Sc}>10$ [McLennan et al., 1993. Th/Sc ratio range from 0.39 to 3.37 (average $=1.49)$ and the $\mathrm{Zr} / \mathrm{Sc}$ ratio range from 0.50 to 51.875 (average $=12.95)$ in the sandstones. When plotted in $\mathrm{Th} / \mathrm{Sc} \mathrm{Vs} \mathrm{Zr} / \mathrm{Sc}$ variation diagram of McLennan et al. 1993 (Figure 7d), it was observed that Gondwana sediments represents both UCC and recycled source.

The values of $\mathrm{La} / \mathrm{Sc}, \mathrm{Th} / \mathrm{Sc}, \mathrm{La} / \mathrm{Co}, \mathrm{Th} / \mathrm{Co}$, and $\mathrm{Cr} / \mathrm{Th}$ values of the Lower Gondwana Group sandstones are more comparable to values for sediments resultant from felsic source rocks than for mafic source rocks (Table 2).

3.1.3. Source Area Weathering. The Chemical Alteration Index (CIA) proposed by Nes- 

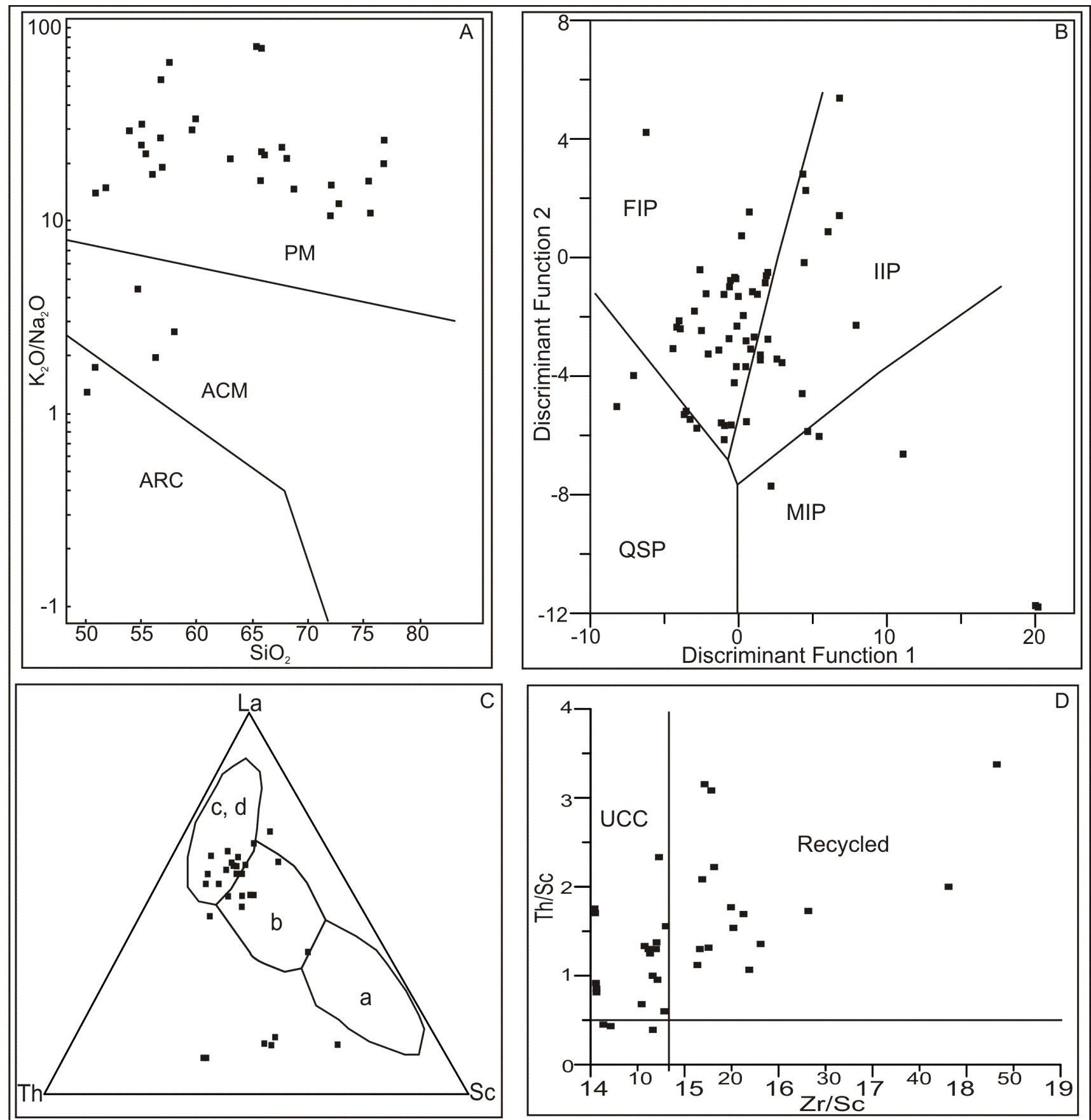

Figure 7. A) Tectonic discrimination diagram for Gondwana sandstones, boundaries after Roser and Korsch 1986, PM = Passive Continental Margin, ACM = Active Continental Margin, ARC=Oceanic Island Arc Margin, B) After Roser and Korsch [1988], $\mathrm{F} 1=\left(-1.773 \mathrm{TiO}_{2}+0.607 \mathrm{Al}_{2} \mathrm{O}_{3}+0.76\left(\mathrm{Fe}_{2} \mathrm{O}_{3}\right)-1.5 \mathrm{MgO}+0.616 \mathrm{CaO}+0.509\right.$ $\left.\mathrm{Na}_{2} \mathrm{O}-1.224 \mathrm{~K}_{2} \mathrm{O}-9.09\right)$ and $\mathrm{F} 2=\left(0.445 \mathrm{TiO}_{2}+0.07 \mathrm{Al}_{2} \mathrm{O}_{3}-0.25\left(\mathrm{Fe}_{2} \mathrm{O}_{3}\right) \mathrm{t}-1.142\right.$ $\left.\mathrm{MgO}+0.438 \mathrm{CaO}+1.475 \mathrm{Na}_{2} \mathrm{O}+1.426 \mathrm{~K}_{2} \mathrm{O}-6.861\right), \mathrm{FIP}=$ Felsic Igneous Province, IIP $=$ Intermdeiate Igneous Province, QSP $=$ Quartzose Sedimentary Province, MIP = Mafic Igneous Province, C) La-Th-Sc ternary plot for Gondwana sandstones. Fields are after Bhatia and Crook 1986, $\mathrm{a}=$ Oceanic Island Arc, $\mathrm{b}=$ Continental Island Arc, $\mathrm{c}=$ Active Continental Margin, $\mathrm{d}=$ Passive Continental Margin, D) Th/Sc $-\mathrm{Zr} / \mathrm{Sc}$ variation diagram of Gondwana sandstones indicating their source (after McLennan et al. 1993), $\mathrm{UCC}=$ Upper Continental Crust. 
Table 2. Range of Elemental Ratios of Lower Gondwana Group Sandstones Compared to Elemental Ratios in Sediments Derived From Felsic Rocks, Mafic Rocks, and in the Upper Continental Crust

\begin{tabular}{ccccc}
\hline $\begin{array}{c}\text { Elemental } \\
\text { ratio }\end{array}$ & $\begin{array}{c}\text { Lower Gondwana } \\
\text { Group sandstones } \\
(n=33)\end{array}$ & $\begin{array}{c}\text { Ranges in } \\
\text { sediments from } \\
\text { felsic sources }\end{array}$ & $\begin{array}{c}\text { Ranges in } \\
\text { sediments from } \\
\text { mafic sources }^{1}\end{array}$ & $\begin{array}{c}\text { Upper } \\
\text { Continental }_{\text {Crust }^{2}}\end{array}$ \\
\hline $\mathrm{La} / \mathrm{Sc}$ & $0.19-6.74$ & $2.50-16.3$ & $0.43-0.86$ & 2.21 \\
$\mathrm{Th} / \mathrm{Sc}$ & $0.39-3.37$ & $0.84-20.5$ & $0.05-0.22$ & 0.79 \\
$\mathrm{La} / \mathrm{Co}$ & $0.07-15.4$ & $1.80-13.8$ & $0.14-0.38$ & 1.76 \\
$\mathrm{Th} / \mathrm{Co}$ & $0.50-14.40$ & $0.04-3.25$ & $0.04-1.40$ & 0.63 \\
$\mathrm{Cr} / \mathrm{Th}$ & $0.06-8.83$ & $4.00-15.0$ & $25-500$ & 7.76 \\
\hline
\end{tabular}

Note: ${ }^{1}$ ) [Cullers, 1994, 2000 Cullers and Podkovyrov, 2000. Cullers et al., 1988. ${ }^{2}$ ) [McLennan, 2001: Taylor and McLennan, 1985 .

bitt and Young 1982 was used to understand the weathering pattern in the source area. The CIA values for the Gondwana sandstones vary from 46.617 to 99.29 , with an average 74.94 which is above the average CIA value of UCC. It indicates that the rocks were likely derived from the weathered soil profiles. In the ternary plot much of the data plot away from the plagioclase-K-feldspar joining line indicating medium to high chemical weathering during sedimentation of the basin (Figure 8 a).

$\mathrm{Th} / \mathrm{U}$ ratio in sedimentary rocks is of importance, as weathering and recycling result in loss of $\mathrm{U}$, leading to an increase in the $\mathrm{Th} / \mathrm{U}$ ratio [McLennan et al., 1993, Rahman et al., 2014. Th/U ra- tios in samples of the study area (25 nos) are in the range of 7.60 to 159.54 , with an average of 29.90 , indicating the derivation of these sediments from recycled crust [Rahman et al., 2014]. The plot of $\mathrm{Th} / \mathrm{U}$ versus Th was used and similar distribution to fine-grained sedimentary rocks as reported by Taylor and McLennan 1985 and normal weathering trend was observed (Figure $8 \mathrm{~b}$ ).

\section{Conclusion}

Geochemistry of the Gondwana sandstones of Arunachal Himalayas indicate chemical coherency

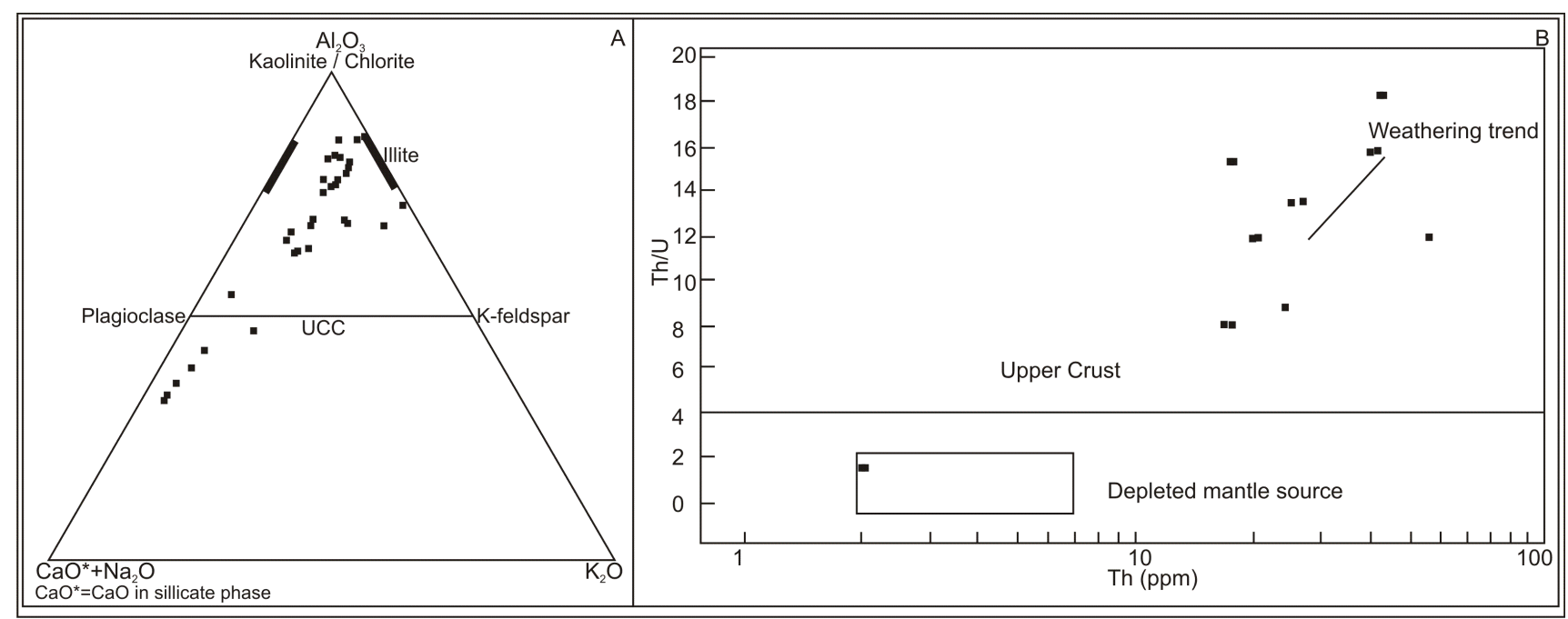

Figure 8. A) CIA ternary diagram, $\mathrm{Al}_{2} \mathrm{O}_{3}-\mathrm{CaO}^{*}+\mathrm{Na}_{2} \mathrm{O}-\mathrm{K}_{2} \mathrm{O}$ (after Nesbitt and Young 1982), B) Th/U versus Th plot (after Taylor and McLennan 1985). 
of the sediments and can be classified as litharenitewacke type. However, in petrography, the sandstones have been classified as sublith arenite. The major oxides represent a passive continental margin average and the trace element abundance is in concurrence with the average Upper Continental Crust with the exception of Th, Sr, K, Nb, P and Zr. The trace element signatures of the sandstones also indicate felsic igneous provenance and represents both Upper Continental Crust and recycled source. Discrimination of tectonic setting on the basis of major elements was used and it was observed that samples are falling in all the three fields, viz. active continental margin, continental island arc and passive margin field of the $\mathrm{Al}_{2} \mathrm{O}_{3} / \mathrm{SiO}_{2}$ versus $\mathrm{Fe}_{2} \mathrm{O}_{3}+\mathrm{MgO} ; \mathrm{K}_{2} \mathrm{O} / \mathrm{Na}_{2} \mathrm{O}$ versus $\mathrm{Fe}_{2} \mathrm{O}_{3}+$ $\mathrm{MgO} ; \mathrm{TiO}_{2}$ versus $\mathrm{Fe}_{2} \mathrm{O}_{3}+\mathrm{MgO}$ plots. But other plots using $\log \left(\mathrm{K}_{2} \mathrm{O} / \mathrm{Na}_{2} \mathrm{O}\right)$ versus $\mathrm{SiO}_{2}$ and $\mathrm{La}-$ Th-Sc concentrations indicate passive margin setting for the sediments. The CIA values indicate considerable weathering in their source areas. The plot of $\mathrm{Th} / \mathrm{U}$ ratio vs $\mathrm{Th}$ for the sandstone samples of the study area suggest derivation of these sediments from recycling of the crust, however the uniform $\mathrm{K} / \mathrm{Rb}$ ratio indicate no or very little elemental redistribution may be due to rapid erosion of fast rising recycled orogens.

Acknowledgment. The authors are gratefull to the Dy. Director General \& HOD, Geological Survey of India, NER, Shillong, Meghalaya, India for permitting the authors to publish the work. The authors also like to express their gratefulness to the anonymous reviewers for critically reviewing the manuscript.

\section{References}

Armstrong-Altrin, J. S., S. P. Verma (2005), Critical evaluation of six tectonic setting discrimination diagrams using geochemical data of Neogene sediments from known tectonic settings, Sedimentary Geology, 177, 115-129, Crossref

Bellanca, A., D. Masetti, R. Neri, et al. (1999), Geochemical and sedimentological evidence of productivity cycles recorded in Toarcian black shales from the Belluno Basin, Southern Alps, northern Italy, Journal of Sedimentary Research, 69, 466476, Crossref

Bhatia, M. R. (1983), Plate tectonics and geochemical composition of sandstones, Journal of Geology, 91, 611-627, Crossref
Bhatia, M. R., K. A. W. Crook (1986), Trace element characteristics of graywackes and tectonic setting discrimination of sedimentary basins, Contributions to Mineralogy and Petrology, 92, 181-193, Crossref

Cullers, R. L., A. Basu, L. J. Suttner (1988), Geochemical signature of provenance in sand-size material in soils and stream sediments near the Tobacco Root batholith, Montana, USA, Chemical Geology, 70, 335-348, Crossref

Cullers, R. L. (1994), The controls on the major and trace element variation of shales, siltstones, and sandstones of Pennsylvanian-Permian age from uplifted continental blocks in Colorado to platform sediment in Kansas, USA, Geochimica et Cosmochimica Acta, 58, 4955-4972, Crossref

Cullers, R. L. (2000), The geochemistry of shales, siltstones and sandstones of Pennsylvanian-Permian age, Colorado, USA: Implications for provenance and metamorphic studies, Lithos, 51, 181-203, Crossref

Cullers, R. L., V. N. Podkovyrov (2000), Geochemistry of the Mesoproterozoic Lakhanda shales in southeastern Yakutia, Russia: Implications for mineralogical and provenance control, and recycling, Precambrian Research, 104, 77-93, Crossref

Crook, K. A. W. (1974), Lithogenesis and geotectonics: the significance of compositional variation in flyscharenites (greywackes), Special publication - Society of Economic Paleontologists and Mineralogists, 19, 304-310,

Dymond, J., E. Suess, M. Lyle (1992), Barium in deep-sea sediment: A geo-chemical proxy for paleoproductivity, Paleoceanography, 7, 163-181, Crossref

Feng, R., R. Kerrich (1990), Geochemistry of fine-grained clastic sediments in the Archean Abitibi greenstone belt, Canada: Implications for provenance and tectonic setting, Geochimica et Cosmochimica Acta, 54, 1061-1081, Crossref

Fyffe, L. R., R. K. Pickerill (1993), Geochemistry of Upper Cambrian-Lower Ordovician black shale along a northeastern Appalachian transect, Bulletin of Geological Society of America, 105, 897-910, Crossref GSI (2010), Geology and Mineral Resources of Arunachal Pradesh, Geological Survey of India, Miscellaneous Publication, 30, No. IV (I), 54.

Herron, M. M. (1986), Geochemical classification of terrigeneous sands and shales from core or log data, Journal of Sedimentary Petrology, 58, 820-829.

Mahanta, B. N., R. K. Sarmah, T. K. Goswami, et al. (2017), Heavy mineral studies of Gondwana sandstones of Eastern Arunachal Himalaya and implications for provenance, Science Vision, 17, 8-14, Crossref

Mahanta, B. N., R. K. Sarmah, T. K. Goswami (2019), Elucidation of Provenance, palaeoclimate and tectonic setting of the Gondwana sandstones of Arunachal Himalayas, Journal of Geological Society of India, 94, No. 3, 260-266, Crossref 
Mahanta, B. N., B. R. Syngai, R. K. Sarmah, et al. (2020), Geochemical composition of Lower Gondwana sandstones of eastern Arunachal Himalayas, India, Earth Science DataBase, GC RAS, Moscow. Crossref

Maynard, J. B., R. Valloni, H. S. Yu (1982), Composition of modern deep-sea sands from arc related basins, Trench and forearc Geology: Sedimentation and Tectonics on Modern and Ancient Active Plate Margins, J.K. Leggett (Ed.), Geological Society of London, Special Publication, 10 p. 551-561, Geological Society of London, London.

McLennan, S. M., S. R. Taylor, K. A. Eriksson (1983), Geochemistry of Archean shales from the Pilbara Supergroup, Western Australia, Geochimica et Cosmochimica Acta, 47, 1211-1222, Crossref

McLennan, S. C., S. Hemming, D. K. McDaniel, et al. (1993), Geochemistry of Archean shales from the Pilbara Supergroup, Western Australia, Geochemeical approach to sedimentation, provenance and tectonics, Geological Society of America, Special Paper, 284 p. 21-40, Geological Society of America, Washington, DC.

McLennan, S. M. (2001), Relationships between the trace element composition of sedimentary rocks and upper continental crust, Geochemistry, Geophysics, Geosystems, 2, No. 4, 1021-1024, Crossref

Nath, B. N., H. Kunzendorf, W. L. Pluger (2000), Influence of provenance, weathering and sedimentary processes on the elemental ratio of the fine-grained fraction of the bed load sediments from the Vembanad Lake and the adjoining continental shelf, southwest coast of India, Journal of Sedimentary Research, 70, 1081-1094, Crossref

Nesbitt, H. W., G. M. Young (1982), Early proterozoic climates and plate motions inferred from major element chemistry of lutites, Nature, 299, 715-717, Crossref

Osae, S., D. K. Asiedu, B. Banoeng-Yakubo, et al. (2006), Provenance and tectonic setting of Late Proterozoic Buem sandstones of southeastern Ghana: Evidence from geochemistry and detrital modes, Journal of African Earth Science, 44, 85-96, Crossref

Peterson, J. A. (2009), Geochemical Provenance of Clastic Sedimentary Rocks in the Western Cordillera: Utah, Colorado, Wyoming, and Oregon, M. S. Thesis, p. 109, Utah State University, Utah, USA.

Rahman, M. J. J., S. S. Suzuki (2007), Geochem- istry of sandstones from the Miocene Surma Group, Bengal Basin, Bangladesh: Implications for Provenance, tectonic setting and weathering, Geochemical Journal, 41, 415-428, Crossref

Rahman, M. J. J., A. S. M. Sayem, T. McCann (2014), Geochemistry and Provenance of the Miocene Sandstones of the Surma Group from the Sitapahar Anticline, Southeastern Bengal Basin, Bangladesh, Journal of Geological Society of India, 83, No. 4, 447-456, Crossref

Roser, B. P., R. J. Korsch (1986), Determination of tectonic setting of sandstone and mudstone suites using $\mathrm{SiO}_{2}$ content and $\mathrm{K}_{2} \mathrm{O} / \mathrm{Na}_{2} \mathrm{O}$ ratio, Journal of Geology, 94, No. 5, 635-650, Crossref

Roser, B. P., R. J. Korsch (1988), Provenance signatures of sandstone-mudstone suites determined using discriminant function analysis of major-element data, Chemical Geology, 67, 119-139, Crossref

Roser, B. P., R. J. Korsch (1999), Geochemical characterization, evolution and source of a Mesozoic accretionary wedge: the Torlesse terrane, New Zealand, Geological Magazine, 136, No. 5, 493512, Crossref

Schmitz, B. (1987), Barium, equatorial high productivity, and the northward wandering of the Indian continent, Paleoceanography, 2, No. 1, 63-77, Crossref

Shaw, D. M. (1968), A review of $\mathrm{K}-\mathrm{Rb}$ fractionation trends by covariance analysis, Geochimica et Cosmochimica Acta, 32, 573-602, Crossref

Siever, R. (1979), Plate tectonic controls on diagenesis, Journal of Geology, 3, 487-490.

Taylor, S. R., S. M. McLennan (1985), The Continental Crust; Its Composition and Evolution, 312 pp. Blackwell, London.

Vdacny, M., A. Vozarova, J. Vozar (2013), Geochemistry of the Permian sandstones from the Maluzina Formation in the Male Karpaty Mts (Hronic Unit, Western Carpathians, Slovakia): implications for source-area weathering, provenance and tectonic setting, Geologia Carpathicas, 64, No. 1, 23-38, Crossref

\section{Corresponding author:}

Bashab N. Mahanta, Geological Survey of India, Shillong, Meghalaya, India. (bn.mahanta@gsi.gov.in; bnmism@gmail.com) 